\title{
Pragmatic Aspects in Anne Hathaway's Speech: A Speech Act Study
}

\author{
Mualimin \\ \{mualimin@lecturer.undip.ac.id\} \\ Universitas Diponegoro, Indonesia
}

\begin{abstract}
This research explores pragmatic aspects in Anne Hathaway's speech addressed on the commemoration of International Mother's Day in the UN forum in 2017. The data of this research are in the form of utterances used in the speech. The data are analyzed using speech act theory of language use which is covered in pragmatics. The results show that based on the theory of speech acts, Anne Hathaway uses four kinds of speech acts covering directives, assertive, expressive, and commissure. There is no declaration found in the speech. In delivering her speech, Hathaway uses an effective language covering both direct and indirect utterances.
\end{abstract}

Keywords: Pragmatic Aspects, Speech Acts, Direct and Indirect Utterances

\section{Introduction}

English is one of the most widely spoken languages of the world and is one of the official languages used in international forum meetings between nations or the United Nations. As an international language, English is not only used as the language of the countries such as the United Kingdom, the United States, Canada, Australia and New Zealand, but also as a second language in countries that are members of the British Commonwealth, or better known as Commonwealth Countries, namely the countries that once became the British colonies.

Acting as a UN ambassador, Anne Jacqueline Hathaway, Anne Hathaway for short, certainly has a mission so that the world communities participate in advocating the rights of children and women. Through the speech, Anne Jacqueline Hathaway tried to convince and invite the audience to take concrete steps. To convince the listener, of course, Anne Jacqueline Hathaway drafted her speech as best as she could, so that what she delivered could influence her listeners.

In composing speech texts, especially those relating to inviting or influencing listeners, Anne Jacqueline Hathaway certainly considered aspects of language related to speech acts. Therefore, this research is considered important to be carried out in order to be able to know the patterns of sentences or utterances so that the results of this study can be at least as a research model in pragmatic English studies which is an area of the writer's research interest.

English is one of the most spoken languages and is one of the official languages used in international forums, meetings between nations or the United Nations. As an international language, English is not only used as the language of countries such as Great Britain, the United States, Canada, Australia and New Zealand, but also as a second language in countries that are members of the British Commonwealth, or better known as Commonwealth Countries, namely countries that were once British colonies. 
Acting as a UN ambassador, Anne Jacqueline Hathaway certainly has a mission for the world community to join in advocating the rights of children and women. Through this speech, Anne Jacqueline Hathaway tried to convince and invite the audience to take concrete steps. To convince listeners, of course, Anne Jacqueline Hathaway composed her speech as best as she could, so that what she said could influence her listeners.

In compiling a speech script, especially those related to engaging or influencing listeners, Anne Jacqueline Hathaway certainly considers aspects of language related to speech acts. Therefore, this research is important to do so that the sentence or speech patterns can be identified so that the results of this study can at least serve as a research model in the pragmatic study of English which is the researcher's area of interest.

This study discusses the pragmatic aspects of the speech of Anne Jacqueline Hathaway, an award-winning artist who advocates the rights of children and women. Anne Jacqueline Hathaway was born on November 12, 1982 in Brooklyn, New York, United States. She was also elected as the UN Ambassador for women's issues (UN Women Goodwill Ambassador) in June 2016. On March 8, 2017 she delivered a speech at the commemoration of UN International Mother's Day with the title "Paid Parental Leave is about Creating Freedom to Divine Roles" [1]. This research refers to one aspect of pragmatic theory, namely the speech act theory which states that language is not only used to say something but also do something [2].

\section{Speech Theory}

Many linguists have done studies related to speech act realization. To mention a few, among others are Blum-Kulka and Olshtain [3], Wierzbicka [4], Trosborg [5], and Hashemian [6]. According to Austin [2], language is not only used to express something but also to carry out an action. According to him, utterances a of language can be divided into two, namely constative utterances and performative utterances. Constative utterance is an utterance used by the speaker to say or tell something, while performative speech is an utterance to do something. For example, if someone says "This room is cold", then that person's utterance can be interpreted as telling his hearer that the air in the room is in a low temperature whose temperature can be measured with a thermometer. However, the same utterance can also mean that the person wants someone else to raise the air temperature in the room by turning on the heater or to increase the air temperature by turning off the air conditioner in the room.

In connection with speech act theory, Searle [7] argues that the meaning of an utterance can have five illocutionary meanings, namely directive, representative (assertive), commissive, expressive, and declaration which are described as follows.

1. Directive is an utterance intended by the speaker that the listener takes action as in mentioned in the utterance. Among the speech acts with directive illocution are ordering, prohibiting or reminding.

2. Representative or assertive is an utterance that is intended by the speaker to state something that is true, according to reality. The truth of a speech can be known by the circumstances at which the speech was said. The examples of representative utterances are, among others, stating, reporting or mentioning.

3. Expressive is the utterance used by the speaker to evaluate or express feelings about something. Examples of expressive speech include saying thanks, praising, and criticizing. 
4. Commissive is an utterance that is used by the speaker to commit himself that he is going to do something. Examples of commissive acts knowing and promising.

5. Declaration is utterance used by speakers to create a new state or new status. The examples of declaration are making decision, naming, appointing, and firing [7].

In reality, speech act can be realized by direct speech and indirect speech. Directive speech, for example, which is expressed directly in English is the utterance "open your book!" In the above utterance, the speaker uses the utterance in the imperative mood, which means the listener does something, which in this case opens the book. For the same purpose, a speaker may use indirect speech, namely using interrogative sentences such as the utterance "Can you open your book?" From the explanation above, it can be seen that a speaker can have certain types of speech acts, either directly or indirectly according to the circumstances when he is going to perform the speech act.

Regarding indirect speech acts, Searle [8] argues that there are six types of utterances used by a speaker. The six types of utterances are 1) utterances related to the speaker's ability, 2) utterances related to the will or desire of the speaker, 3) utterances related to what the listener does, 4) utterances related to the listener's desire or willingness to take action, 5) utterances related to the reasons for the need for an action, and 6) utterances which are a combination of the five above.

\section{Methodology}

The method used in this research is qualitative with non-participatory observation with note-taking technique [9]. The data of this research are in the forms of utterances found in a speech addressed by Anne Jacqueline Hathaway on March 8, 2017 which she delivered at the commemoration of UN International Mother's Day with the title "Paid Parental Leave is about Creating Freedom to Divine Roles". Thus, the data sources of this research are all the utterances that have illocutionary, directive, repetitive, expressive, commissure, and declarative meanings used by Anne Jacqueline Hathaway in her speech. There are 85 sentences in the speech addressed in 12 minutes, 44 seconds.

Data collection was carried out by means of observation. Observations were made by observing each utterance which has the meaning of directive, repressive, expressive, commissure, and declarative illocution in the speech. Note taking technique is carried out by identifying and classifying each utterance that has 5 illocutions, either directly or indirectly and of course by paying attention to the context and situation of the utterance. Data analysis was carried out inductively and was carried out since the discovery of the phenomenon of the use of speech acts in the speech. From the data collected, it is then examined more closely in relation to the factors that influence the use of speech act in Anne Jacqueline Hathaway's speech, which is the object of this study.

\section{Results and Discussion}

Based on the finding, the followings are the discussion on the use of speech acts found in the speech addressed by Hathaway. Among five illocutionary meanings only four of them are discovered in the speech. The speech acts found in the speech are namely directives, representatives, expressive, and commissure, and there is no declaration speech act found in 
the speech. The use of the speech acts in Hathaway's speech can be seen in the following table.

Based on the finding, the followings are the discussion on the use of speech acts found in the speech addressed by Hathaway. Among five illocutionary meanings only four of them are discovered in the speech. The speech acts found in the speech are namely directives, representatives, expressive, and commissive, and there is no declaration speech act found in the speech. The use of the speech acts in Hathaway's speech can be seen in the following table.

Table 1. The use of speech acts in Hathaway's speech

\begin{tabular}{|c|l|c|c|}
\hline No & Speech Acts & Freq. & $\%$ \\
\hline 1 & Directive & 16 & 18.8 \\
\hline 2 & Representative & 21 & 24.7 \\
\hline 3 & Expressive & 44 & 51.8 \\
\hline 4 & Commissure & 4 & 4.7 \\
\hline 5 & Declaration & 0 & 0 \\
\hline & Total & 85 & 100 \\
\hline
\end{tabular}

It can be seen from Table 1 that there are 85 utterances discovered in the speech addressed by Hathaway, but not all of the speech acts are discovered in the speech. Expressive is the mostly used speech act which covers 44 utterances or more than half of the whole utterances used in the speech $(51,8 \%)$. The second mostly used speech acts is representative covering 21 utterances or $24.7 \%$ of the whole utterances. The last three speech acts used are namely, directive speech acts $(18.8 \%)$, commissure speech acts $(4.7 \%)$ and Declaration speech acts $(0 \%)$.

The high frequency of the expressive used in a speech is undoubtedly explainable due to the fact that a speech in general is a kind of expression addressed by a speaker to his/her audiences so that every message delivered can be conveyed and understood the audience. In the speech Hathaway expresses her feeling about what has happened around her life since he was a young artist. How her parents have taught her to be aware of the direction. As a UN ambassador she thought that she could do something related to the situation dealing with the rights of mothers and children.

Apart from expressive, Hathaway also uses representative speech acts in which she expresses her feeling with statistic data to support her ideas related to the working condition in her own country, the USA.

The third speech acts used in the speech is directive in which the utterance is meant by the speaker that the hearer does something related with the condition around the globe concerning the rights of mothers and children. By using the directive speech acts Hathaway tells the audience which are representative of their nations to do something to advocate the rights of mothers and children to make a better family life in their countries. In fact, the real objective of giving a speech in the UN forum is to ask the audience to make efforts in relation to the life of mothers and children even the life of a family because family problems involve father, mothers, children, and also the government of the nation where the family live.

The last two speech acts used in the speech are commissive and declaration. A commissive utterance is an utterance that commit the speaker to do something. In her speech, Hathaway plan to do something as her commitment to deal with the rights of mothers and children. In line with her role as a UN ambassador, Hathaway has no rights to make a UN 
decision, consequently she is not eligible to declare something in front of the audience. Accordingly, there is no declaration used in the speech.

The following is the use of each speech act discovered in the Hathaway's speech and the discussion of every utterance with several examples from each speech act. In this paper the order of the discussion is based on the description of each speech act as mentioned earlier.

\subsection{Directive}

The directive utterances can be seen in the following examples

(1) "In other words, in order to liberate women, we need to liberate men"

(2) "So why do we continue to undervalue fathers and overburden mothers?"

(3) "We need to help each other if we are going to grow."

(4) "We can do this."

(5) "Every generation must find their north."

In (1) and (3) the speaker means that as an ambassador of the UN she asks the audience to liberate men and people should help each other in a sense that to have a better family the fathers don not only have to work out of their house, but also have enough time with their family at home. In this utterance, the speaker uses indirect directive utterance by using a declarative sentence. In (2) the speaker also uses directive utterance by using interrogative sentence. By using the utterance, the speaker means that people should not undervalue fathers and overburdens mothers. This utterance includes indirect directive utterance. In (4) and (5) the speaker asks the audience to do something to make a better family life. In 4 the speaker asks the audience by stating that they can do something, and in (5) the speaker urges the audience to make their own way to make a better life.

\subsection{Representative}

The representative or assertive utterances can be seen from the following examples.

(6) "When I was a very young person, I began my career as an actress."

(7) "Whenever my mother wasn't free to drive me into Manhattan for auditions, I would take the train from suburban New Jersey and ...."

(8) "We would then get onto the subway together and, when we surfaced, he would ask me "Which way is north?"

(9) "American women are currently entitled to 12 weeks' unpaid leave. American men are entitled to nothing."

From utterance (6) to (9) the speaker tells the audience the fact about her life as an actress in (6) and also her experiences how their parents have helped her understand the life surrounding her family as mentioned in (7) and (8). Her father and mother have helped her to find as simple as the direction. In (9) she shows the fact that American are allowed not to work without pay but the fathers are not allowed to have unpaid leave. As it is known that representative is an utterance in which the speaker tells the listeners about the facts related to her experience in life and also the fact about taking leave from work in her own country, the USA.

\subsection{Expressive}

(10) 'I wasn't very good at finding North at the beginning, but I auditioned fair amount and My Dad kept asking me "Which way is north?" 
(11) "Over time, I got better at finding it."

(12) "I was struck by that memory yesterday while boarding the plane to come here."

(13) "When I was still a child, my father developed my sense of direction and now, as an adult, I trust my ability to navigate space."

(14) "That information landed differently for me when one week after my son's birth I could barely walk."

(15) "Thank you."

In utterance (10) to (15), the speaker uses expressive speech acts in which the speaker expresses her feelings about social phenomena surrounding her life. In (10) she tells the audience that at first, she had difficulty to find direction, but later on she knows the direction well as mentioned in (11). In (12) and (13) she tells the audience how her father has helped her life even finding way to do boarding the plane on the day to come to the meeting. In (14) she expresses her feeling when she had to work only one week after giving birth. In (15) she thanks the audience that she has been given a chance to give a speech in front of the representatives of all countries allied in the United Nation.

\subsection{Commissive}

(16) "I look forward to beginning with the UN itself which has not yet achieved parity and who's paid parental leave policies are currently up for review."

(17) "All you're going to see a lot of me."

(18) "If 100,000 people become 100 million. A billion. More."

In (16) to (18) the speaker intends to do something in the future by inviting the UN to have parental leave policy so that more people in the world will take roles as social agents to make a better family life

\section{Conclusion}

A speech as a kind of communication has certain characteristics in terms of utterances used in the speech. The speech addressed by Hathaway, a UN ambassador at the UN forum covers four out of five speech acts. The use of each speech act is as follows: directives (18\%), representatives (24\%), expressive $(51 \%)$, commissure $(4 \%)$. There is no declaration speech act used in the speech. The use of these speech indicates that the speech has been well prepared by the speaker in terms of language use. This characteristic also reflects that the speech covers all speech acts needed and it has been well scripted.

\section{Acknowledgement}

I would like to express my gratitude to the dean of the Faculty of Humanities, Universitas Diponegoro who has supported me to conduct this research so that this article can be published in this international conference.

\section{References}

[1] A. J. Hathaway, "'Paid Parental Leave is about Creating Freedom to Divine Roles" a speech 
addressed on the commemoration of International Mother's Day on March 8," 2017.

[2] J. L. Austin, "How to Do Things with Words New York: Oxford Univ," Press. 1965Austin1965How to Do Things with Words, 1962.

[3] S. Blum-Kulka and E. Olshtain, "Requests and apologies: A cross-cultural study of speech act realization patterns (CCSARP)," Appl. Linguist., vol. 5, no. 3, pp. 196-213, 1984.

[4] A. Wierzbicka, Cross-cultural pragmatics. Walter de Gruyter Inc, 2003.

[5] A. Trosborg, Pragmatics across languages and cultures, vol. 7. Walter de Gruyter, 2010.

[6] M. Hashemian, "A pragmatic study of requestive speech act by Iranian EFL Learners and Canadian native speakers in hotels," J. Teach. Lang. Ski., vol. 33, no. 2, pp. 1-25, 2014.

[7] J. R. Searle, "A classification of illocutionary acts," Lang. Soc., pp. 1-23, 1976.

[8] J. R. Searle, "Indirect speech acts," in Speech acts, Brill, 1975, pp. 59-82.

[9] Sudaryanto, Metode dan aneka teknik analisis bahasa: pengantar penelitian wahana kebudayaan secara linguistis. Duta Wacana University Press, 1993. 